\title{
Influence of the Starting Materials on Performance of High Temperature Oxide Fuel Cells Devices
}

\author{
Emília Satoshi Miyamaru Seo*, Walter Kenji Yoshito, Valter Ussui, Dolores Ribeiro Ricci \\ Lazar, Sonia Regina Homem de Mello Castanho, José Octavio Armani Paschoal \\ IPEN - Instituto de Pesquisas Energéticas e Nucleares of São Paulo \\ Prof. Lineu Prestes Avenue, 224, 05508-000 Campus USP, São Paulo - SP, Brazil
}

Received: September 2, 2002; Revised: September 4, 2002

\begin{abstract}
High temperature solid oxide fuel cells (SOFCs) offer an environmentally friendly technology to convert gaseous fuels such as hydrogen, natural gas or gasified coal into electricity at high efficiencies. Besides the efficiency, higher than those obtained from the traditional energy conversion systems, a fuel cell provides many other advantages like reliability, modularity, fuel flexibility and very low levels of $\mathrm{NO}_{\mathrm{x}}$ and $\mathrm{SO}_{\mathrm{x}}$ emissions. The high operating temperature $\left(950-1000{ }^{\circ} \mathrm{C}\right)$ used by the current generation of the solid oxide fuel cells imposes severe constraints on materials selection in order to improve the lifetime of the cell. Besides the good electrical, electrochemical, mechanical and thermal properties, the individual cell components must be stable under the fuel cell operating atmospheres. Each material has to perform not only in its own right but also in conjunction with other system components. For this reason, each cell component must fulfill several different criteria. This paper reviews the materials and the methods used to fabricate the different cell components, such as the cathode, the electrolyte, the anode and the interconnect. Some remarkable results, obtained at IPEN (Nuclear Energy Research Institute) in São Paulo, have been presented.
\end{abstract}

Keywords: $S O F C$, cathode, anode, electrolytes, interconnect

\section{Introduction}

Fuel cells operate by an electrochemical combination of a fuel with an oxidant without hot combustion. This is achieved by placing an electrolyte between two electrodes in contact with the fuel and the oxidant, respectively. An ideal electrolyte can conduct ions, but no electrons, in order to combine the fuel (e.g. hydrogen) with the oxidant (e.g. air). In a fuel cell, the oxygen has to be reduced to oxygen ions at the cathode side of the electrolyte so that they can be transported by ionic conduction through the electrolyte. At the anode side of the electrolyte, the oxygen ions combine with the hydrogen producing water and electrons ${ }^{1}$. The driving force will be the oxygen gradient in the oxidant gas (air) and the fuel gas mixture with low partial oxygen pressure. In the case of a proton conducting electrolyte, hydrogen ions migrate through the electrolyte from anode to cathode. The external circuit, that transports the electrons released at the anode side by hydrogen oxidation, supplies the electrons for oxygen reduction reaction at the cathode side.
Solid oxide fuel cells have been known for more than 60 years and were first created by Bauer and Preis in 1937. However the development of practically usable SOFCs only started in the beginning of the 1960's².

The use of only solid materials requires less maintenance and, in general, simplifies the operation. As the electrolyte is solid, the layers can be thinner. Thus, the solid oxide fuel cells can be more compact than those that use liquid electrolytes.

Another advantage of the SOFCs is that as they operate at higher temperatures, in comparison to the other types of fuel cells, there is no need of expensive noble metal catalysts at the electrodes. The high temperature allows the use of the waste heat for room heating (small units) or the generation of electricity by steam turbines cogeneration (larger plants $)^{1}$. One disadvantage of the SOFCs is that they are more prone to mechanical failure that can short out individual cells, resulting in hot combustion of the fuel and leading to lower efficiency. Rapid start up of a solid oxide fuel 
cell results in high thermal stresses caused by large thermal gradients within the fuel cells. To use commercially the solid oxide fuel cells, all these problems have to be overcome.

Because of the high operating temperatures of the present SOFCs (approximately $1000^{\circ} \mathrm{C}$ ), the materials used in the cell components are limited by chemical stability in oxidizing and reducing atmospheres, chemical stability in contact with the other materials (interfaces), conductivity and thermomechanical compatibility.

The state-of-the-art electrolyte material for SOFCs is yttria-stabilized zirconia (YSZ) ${ }^{1,3}$. Thin electrolytes have been used to lower the ohmic losses as all suitable materials for fuel cells have low ionic conductivities. On the other hand, the use of thin electrolytes results in others problems. In order to achieve high efficiency, the electrolyte must be dense and free of cracks. The most common anode material is a cermet of metal nickel and $\mathrm{YSZ}^{1,4,5}$. Nickel has a large mismatch in thermal expansion compared to the YSZ used in the electrolyte, preventing the use of a whole nickel electrode. The cermet both reduces/prevents thermal mismatch between the nickel and the YSZ and produces a large three phases boundary. One problem caused by the use of the cermets is the nickel sintering over time, that reduces the active surface of the electrode ${ }^{3}$. However, this can be minimized by control of the grain size and microstructure of the cermet.

Strontium doped-lanthanum manganite (LSM) is the preferred material for cathode application ${ }^{7,8}$. This material is able to operate as an air electrode under an oxidizing environment of air or oxygen at $\sim 1000{ }^{\circ} \mathrm{C}$. The main characteristics required are high electronic conductivity, chemical and dimensional stability under the cell environments during the operation, thermal expansion match with other cell components and sufficient porosity to facilitate the transport of molecular oxygen from the gas phase (air) to the electrode/electrolyte interface ${ }^{6,8}$.

Lanthanum chromite $\left(\mathrm{LaCrO}_{3}\right)$ is particularly an attractive material as interconnect for solid oxide fuel cells (SOFCs) because of the good electronic conductivity in air, reasonable conductivity in the fuel atmosphere, good stability in the fuel cell environment and compatibility with other fuel cell components. Interconnect provides electrical connection among the individual cells and acts as gas barrier among them. A primary requirement for potential interconnect materials is the density that has to be high enough to prevent cross leakage of fuel and oxidant gases ${ }^{1,5}$.

The SOFC Program has been developed for a short time at IPEN, but remarkable results, obtained from performance and interaction studies of the SOFC components, may provide interesting contributions to the materials development for fuel cells applications and also to further developments at the Institute.

\section{Studies and Developments in SOFC Experience at IPEN}

A solid oxide fuel cell essentially consists in two porous electrodes separated by a dense oxygen ion conducting electrolyte. The materials of the different cell components have been selected based on the following criteria: suitable electrical conducting properties; adequate chemical and structural stability at high temperatures during the cell operation as well as during the cell fabrication; minimal reactivity and interdiffusion among the different cell components; and matching thermal expansion among the different cell components.

In addition to the above materials selection criteria, synthesis and fabrication processes have been investigated by the IPEN Fuel Cell Researchers Group. These are discussed below for the different cell components.

\subsection{Cathode (Air Electrode)}

The perovskite-type strontium-doped lanthanum manganites have been studied as the most promising candidate material for the of SOFCs cathode ${ }^{8-12}$. With operating temperature up to $1000{ }^{\circ} \mathrm{C}$ in air or oxygen atmosphere, the cathode material has to fulfill the following requirements: high electron conductivity, thermal and chemical stability, compatibility with the solid electrolyte, sufficient porosity and good adherence at the surface of the electrolyte ${ }^{13}$. Many results ${ }^{12-13}$ about synthesis processes of Sr-doped lanthanum manganites have been published. In our investigations, $\mathrm{La}_{(1-\mathrm{x})} \mathrm{Sr}_{\mathrm{x}} \mathrm{MnO}_{3}$ powders have been prepared by high-temperature solid-state reaction of $\mathrm{La}_{2} \mathrm{O}_{3}, \mathrm{SrCO}_{3}$, and $\mathrm{MnCO}_{3}$. Figure 1 shows representative SEM micrograph of $\mathrm{La}_{0 \cdot 60} \mathrm{Sr}_{0.40} \mathrm{MnO}_{3}$ powders prepared using traditional ceramic processing method.

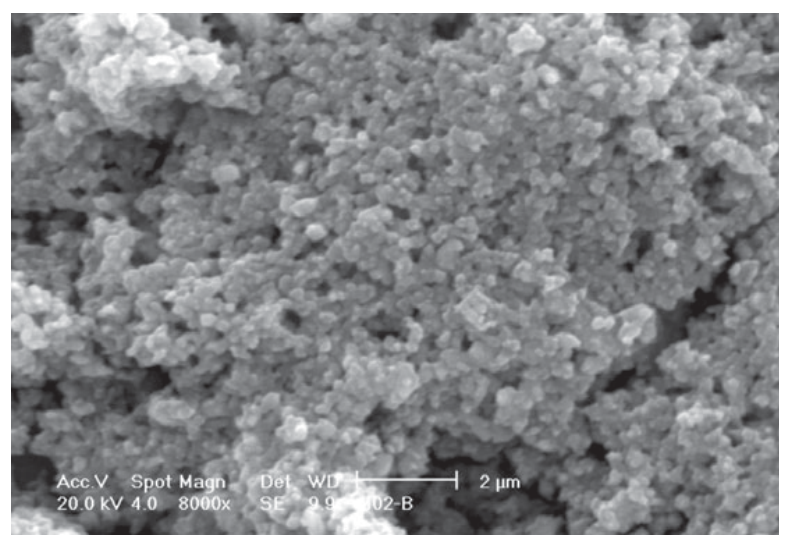

Figure 1. SEM micrograph of $\mathrm{La}_{0}{ }_{60} \mathrm{Sr}_{0.40} \mathrm{MnO}_{3}$ powders after synthesis and calcination at $1200{ }^{\circ} \mathrm{C}$. 


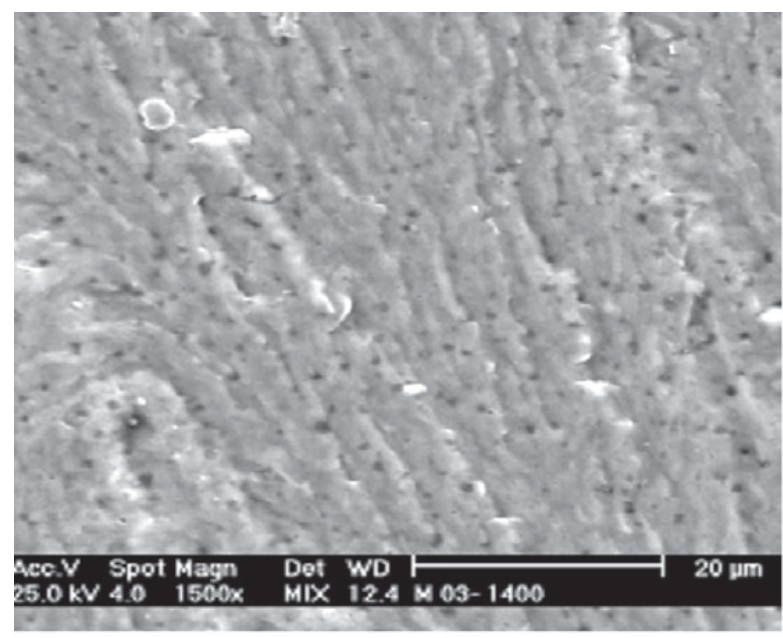

a)

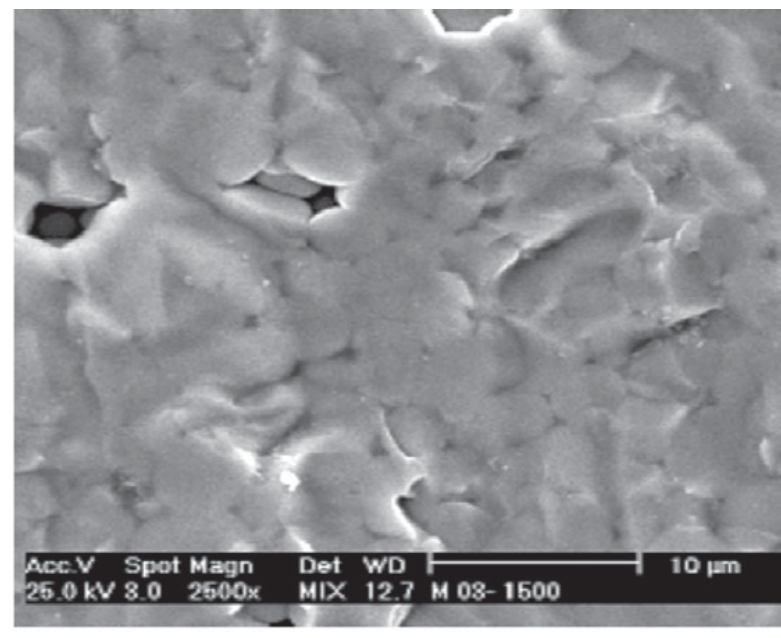

b)

Figure 2. SEM micrographs of samples sintered at $1400{ }^{\circ} \mathrm{C} / 4 \mathrm{~h}(\mathrm{a}) ; 1500{ }^{\circ} \mathrm{C} / 4 \mathrm{~h}(\mathrm{~b})$.

The XRD patterns of the sintered samples indicated the formation of a single-phase solid solution with perovskitelike structure, where the $\mathrm{Sr}^{2+}$ ions are expected to occupy $\mathrm{La}^{3+}$ sites. For samples sintered at $1400^{\circ} \mathrm{C}$, an orthorhombic structure of $\mathrm{La}_{0.50} \mathrm{Sr}_{0.50} \mathrm{MnO}_{3}$ composition was determined ${ }^{14}$. At $1500^{\circ} \mathrm{C}$, a slight modification to monoclinic structure of $\mathrm{La}_{0.60} \mathrm{Sr}_{0.40} \mathrm{MnO}_{3}$ composition was obtained. These compositions such as $\mathrm{La}_{0 \cdot 60} \mathrm{Sr}_{0.40} \mathrm{MnO}_{3}$ and $\mathrm{La}_{0.50} \mathrm{Sr}_{0.50} \mathrm{MnO}_{3}$ were prepared using traditional ceramic processing methods. The densities of these sintered samples $\left(1500{ }^{\circ} \mathrm{C}\right.$ for $4 \mathrm{~h}$ ) are $91 \%$ of the theoretical density.

Figure 2 shows SEM micrographs of samples sintered at $1400{ }^{\circ} \mathrm{C}\left(\mathrm{La}_{0.50} \mathrm{Sr}_{0 \cdot 50} \mathrm{MnO}_{3}\right)$ and $1500{ }^{\circ} \mathrm{C}\left(\mathrm{La}_{0 \cdot 60} \mathrm{Sr}_{0.40} \mathrm{MnO}_{3}\right)$ for $4 \mathrm{~h}$. The micrograph of the sample sintered at $1400{ }^{\circ} \mathrm{C}$ (Fig. 2a) shows small voids while the sample sintered at $1500{ }^{\circ} \mathrm{C}$ (Fig. 2b) shows large voids among aggregated lumps.

A literature study $y^{7,11}$ has proposed that the difference between Sr-doped lanthanum manganites and YSZ coefficients is not larger than $2.6 \times 10^{-6} \mathrm{deg}^{-1}$. In this work, the thermal expansion coefficient of $\mathrm{La}_{0.60} \mathrm{Sr}_{0.40} \mathrm{MnO}_{3}$ calculated from the slope of the curve was $12.8 \times 10^{-6} \mathrm{C}^{-1}$ at $1000^{\circ} \mathrm{C}$. In fact, this result is very similar to that obtained for yttria stabilized zirconia, YSZ, $\left(10.3 \times 10^{-6} \mathrm{deg}^{-1}\right.$ in air $)$, the electrolyte of SOFC. Based on these results, it was demonstrated that the composition of $\mathrm{La}_{0.60} \mathrm{Sr}_{0.40} \mathrm{MnO}_{3}$ is one of the candidates adopted for use as SOFC electrode, because it was verified that these data are compatible with the value of the electrolyte (YSZ) mentioned in the literature $\left(10.3 \times 10^{-6} \mathrm{deg}^{-1}\right)$. For this composition, the value of the thermal expansion coefficient diverges by no more than $2.6 \times 10^{-6} \mathrm{deg}^{-1}$.

However, an electrical conductivity of $4.634 \Omega^{-1} \mathrm{~cm}^{-1}$ for $\mathrm{La}_{0.60} \mathrm{Sr}_{0.40} \mathrm{MnO}_{3}$ at $735^{\circ} \mathrm{C}$, with a sample density of $91 \%$ of

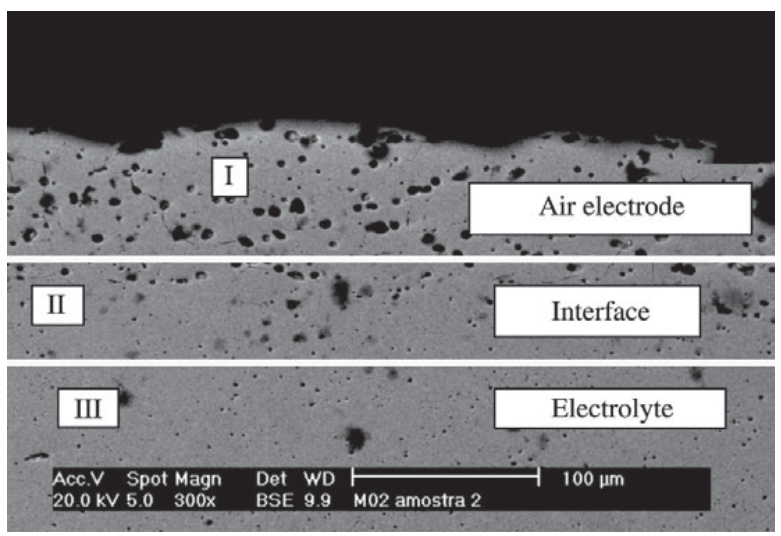

Figure 3. SEM micrograph of a porous cathode deposited via slurry coating on an electrolyte substrate.

the theoretical value, was determined.

Coated films with $57 \pm 0.3 \mu \mathrm{m}$ of thickness were measured by SEM and microstructural investigation of these multiple coatings shows pore shape and size (Fig. 3). The mean pore size is in the range of 1.6 to $2.6 \mu \mathrm{m}$.

Remarks: $\mathrm{La}_{0.60} \mathrm{Sr}_{0.40} \mathrm{MnO}_{3}$ composition has been obtained in the Fuel Cell Program at IPEN with adequate structural and electrical specifications for use as cathode in solid oxide fuel cell. Cathode-electrolyte interface interactions have been studied with good results.

\subsection{Electrolyte}

Cubic stabilized zirconia (CSZ) is a pure oxygen ion conductor and the most common material used for solid oxide fuel cell electrolyte due to its availability and rela- 
tively low $\cos ^{15}$. To achieve a good performance, powders have been synthesized by the coprecipitation route ${ }^{16}$, using aqueous solutions of zirconium and yttrium pure salts or yttrium concentrates, mixed in the desired proportions. The use of yttria concentrates has been studied to reduce the product cost. The reaction is carried out with ammonia solution. To eliminate hard agglomerates the precipitate is filtered, washed with water and treated with organic solvents by azeotropic distillation. The mixed hydroxides are dried at $80{ }^{\circ} \mathrm{C}$ and calcined at $800{ }^{\circ} \mathrm{C}$ resulting in small particles grouped in soft agglomerates as is shown in Fig. 4a. The powders are pressed in cylindrical ceramic bodies and sintered at $1500{ }^{\circ} \mathrm{C}$ for $1 \mathrm{~h}$. Figure $4 \mathrm{~b}$ shows a SEM micrograph of a thermally etched, CSZ ceramic with 9 mol \% of yttria with cubic grain size at about $4 \mu \mathrm{m}$. The achieved ionic conductivity of this sintered product is near to $1.3 \Omega^{-1} \mathrm{~cm}^{-1}$ at $1000^{\circ} \mathrm{C}$.

Remarks: Sintered cubic stabilized zirconia with electrical specification for SOFC electrolytes was obtained.

\subsection{Anode (Fuel Electrode)}

The YSZ-Ni powders preparation has been investigated by two different routes, mechanical mixing of oxide powders $^{17}$ and a coprecipitation of metal salt solutions ${ }^{18}$. In the first process, a commercial $\mathrm{NiO}$ powder and a zirconia-yttria prepared by the same process adopted for the electrolyte were used. The $\mathrm{NiO}$ powder was ground to about $1 \mu \mathrm{m}$, approximately the same size of the YSZ powder. Both powders were mixed in an agate mortar and the produced powders were characterized by scanning electron microscopy. The surface area and the particle size were measured using the BET technique and the laser diffraction method, respectively. Figure 5a shows a typical $\mathrm{ZrO}_{2}-\mathrm{Y}_{2} \mathrm{O}_{3}-\mathrm{NiO}$ powder. These powders were then pressed as cylindrical pellets that were sintered at $1600{ }^{\circ} \mathrm{C}$ for $4 \mathrm{~h}$. Zirconia with $8 \mathrm{~mol} \%$ yttria was chosen for this work, while the Ni content was in the range of 20 to $75 \mathrm{wt} \%$. Figure $5 \mathrm{~b}$ shows the SEM micrograph of a thermally etched YSZ-NiO composite with 54 wt.\% NiO. Dark gray grains (NiO-rich phase) are large, indicating a fast grain growth, and the light gray grains are $\mathrm{ZrO}_{2}$ rich phases.

The coprecipitation process consists in a preparation of metal salt aqueous solutions that are mixed with the appropriate proportions in an experimental apparatus. This mixed solution is sprayed in an ammonium hydroxide solution. The precipitate is then set to sedimentation and the concentration of remaining cations in the supernatant is analyzed by ICP spectrometry to determine the process yield. The precipitate is filtered and submitted to the same process of the electrolyte preparation. The ceramic powder is pressed as cylindrical pellets. The $\mathrm{NiO}$ phase must be reduced to form a continuous $\mathrm{Ni}$ metal phase. The reduction process is done with a hydrogen/argon gaseous mixture in a system assembled in a high temperature tube furnace.

\subsection{Interconnect}

Few oxide systems have been considered as SOFC interconnect material due to the stringent requirements for this fuel cell component. Lanthanum chromite $\left(\mathrm{LaCrO}_{3}\right)$ is particularly suitable because of the high electronic conductivity under fuel and oxidant atmospheres, stability in the fuel cell environment and compatibility with other cell components. A primary requirement for potential interconnect materials is the high density to prevent cross leakage of fuel and oxidant gases.

It is well known that the $\mathrm{LaCrO}_{3}$ is difficult to sinter to high densities under high oxygen activity conditions. The poor sinterability of $\mathrm{LaCrO}_{3}$ in air or oxidizing atmospheres has been ascribed to the formation of a thin layer of $\mathrm{Cr}_{2} \mathrm{O}_{3}$ (from $\mathrm{CrO}_{3}$ gases) at the inter-particle neck, during the ini-

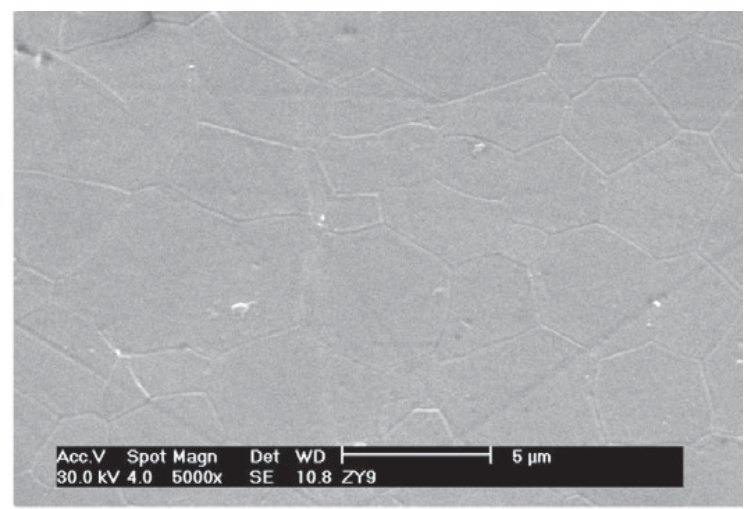

b)

Figure 4. SEM micrograph of the powder (a); the thermally etched $\mathrm{ZrO}_{2}$ with 9 mol\% $\mathrm{Y}_{2} \mathrm{O}_{3}$ (b). 


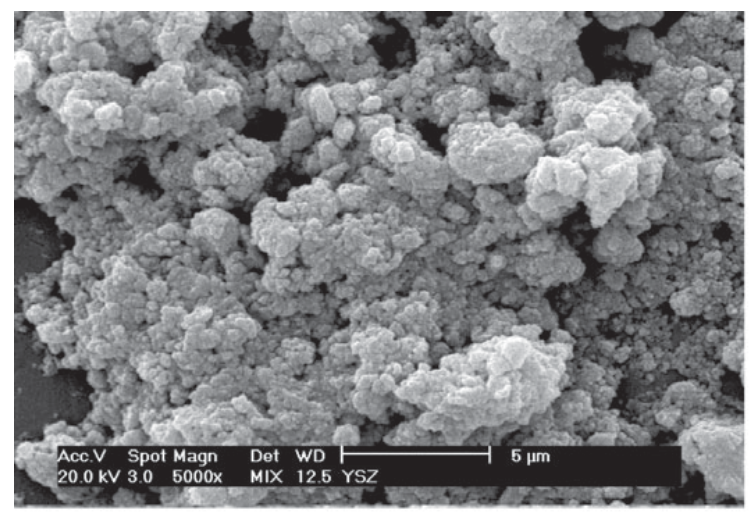

a)

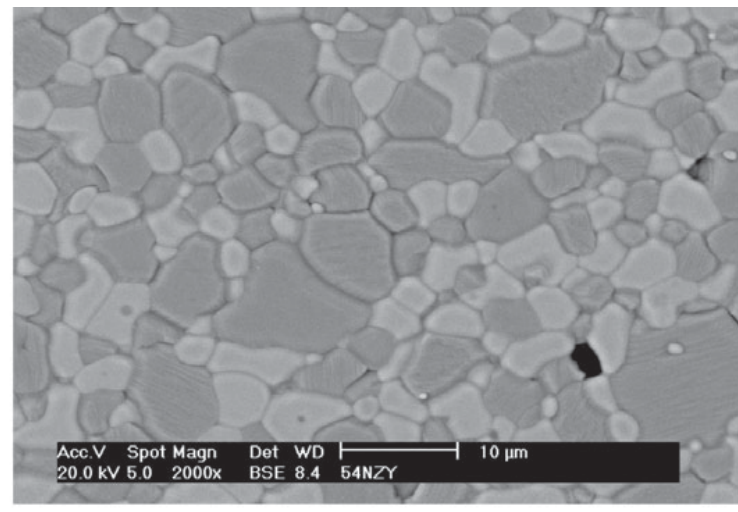

b)

Figure 5. SEM micrograph of the YSZ-12.5\%wt NiO powder (a); the thermally etched YSZ-54wt\% NiO ceramic (b).

tial stage of sintering. Because of the high volatility of chromium oxides, in order to sinter $\mathrm{LaCrO}_{3}$ to high densities, firing temperatures higher than $1660^{\circ} \mathrm{C}$ under low oxygen partial pressures have been currently used ${ }^{19}$. The densification process has been improved by the use of sintering additives or powders which are highly reactive (high surface area) $)^{19,20}$.

At IPEN, the research on interconnect materials has been focused on two different synthesis routes using two kinds of starting materials, national and imported ones. In addition it has been studied the influence of the sintering additives on the final properties of the $\mathrm{LaCrO}_{3}$.

Lanthanum chromite with $30 \mathrm{~mol} \%$ cobalt $\left(\mathrm{LaCr}_{0.7} \mathrm{Co}_{0.3} \mathrm{O}_{3}\right)$ has been synthesized by two different methods: the conventional mechanical mixing of the powders and the combustion reaction.

XRD patterns of as-synthesized powders showed peaks of the $\mathrm{LaCr}_{0,7} \mathrm{Co}_{0.3} \mathrm{O}_{3}$ crystalline phase, that were related to both routes studied.

$\mathrm{LaCr}_{0.7} \mathrm{Co}_{0.3} \mathrm{O}_{3}$ powders, resultant from the mechanical mixing route and after the calcination treatment, presented agglomerate size of $1.29 \mu \mathrm{m}$ (sample A) and $1.44 \mu \mathrm{m}$ (sample B) for pure and concentrated oxides, respectively. For powders obtained by the combustion reaction synthesis, the agglomerate size was $7.38 \mu \mathrm{m}$ (sample C). Studies on combustion synthesis process ${ }^{21}$ have been attributed this difference to the related energies during the chemical reactions. The SEM micrograph of the sample (Fig. 6) reveals agglomerates constituted by interconnected nanoparticles.

The density values of the samples A, B and C, sintered at $1500{ }^{\circ} \mathrm{C}$ for $3 \mathrm{~h}$ in air atmosphere, were $99.1,98.4$ and $85.8 \%$ of the theoretical density, respectively. The difference in the density values reveals that the synthesis process interferes markedly on final properties of the sintered material. The greatest density difference arises from the agglom-

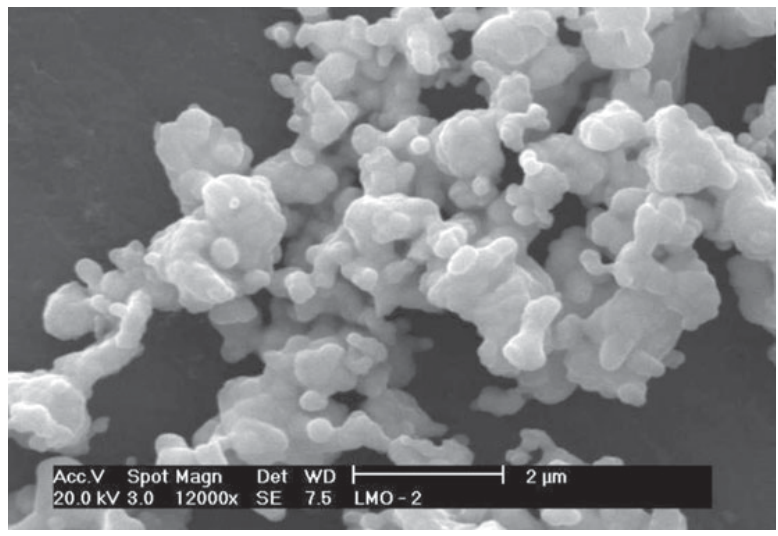

Figure 6. SEM micrograph of the $\mathrm{LaCr}_{0.7} \mathrm{Co}_{0.3} \mathrm{O}_{3}$ agglomerates, synthesized by combustion reaction method.

erated primary particles of the powders synthesized by combustion reaction. SEM micrographs of the polished and thermally etched surfaces of the sintered samples (Fig. 7) show an homogeneous and uniform microstructure for the ceramic obtained from powders prepared by mechanical mixing (Fig.7a) and reaction combustion route (Fig. 7b).

The electrical resistivity measurements of the $\mathrm{LaCr}_{0.7} \mathrm{Co}_{0.3} \mathrm{O}_{3}$ pellets were performed by the two points technique. The resistive electrical behavior as a function of the temperature of the samples synthesized by the different synthesis processes routes reveals the influence of the sintered density. The samples A and $\mathrm{B}$ have presented resistivity values $\left(\right.$ at $250{ }^{\circ} \mathrm{C}$ in air atmosphere) of 1.86 and $1.97 \Omega . m$, respectively; while the sample $\mathrm{C}$ (combustion reaction process) showed $0.8197 \Omega$.m at the same measurement conditions.

Remarks: Both synthesis routes are able to produce $\mathrm{LaCr}_{0.7} \mathrm{Co}_{0.3} \mathrm{O}_{3}$ powders that result in ceramics with high densities and adequate electrical characteristics for inter- 


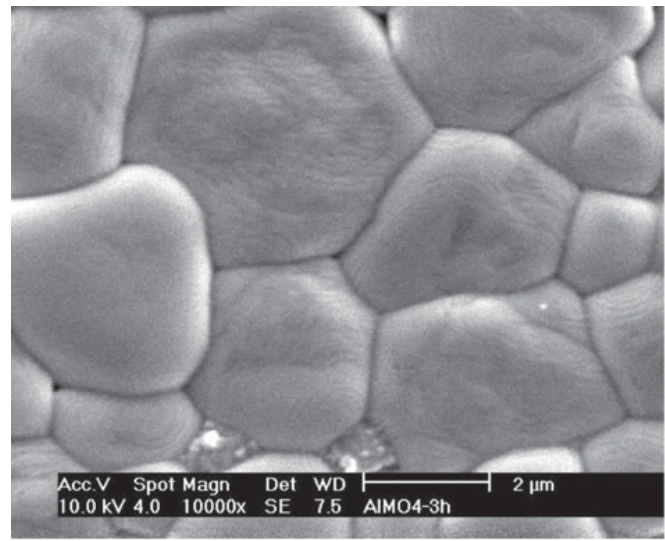

a)

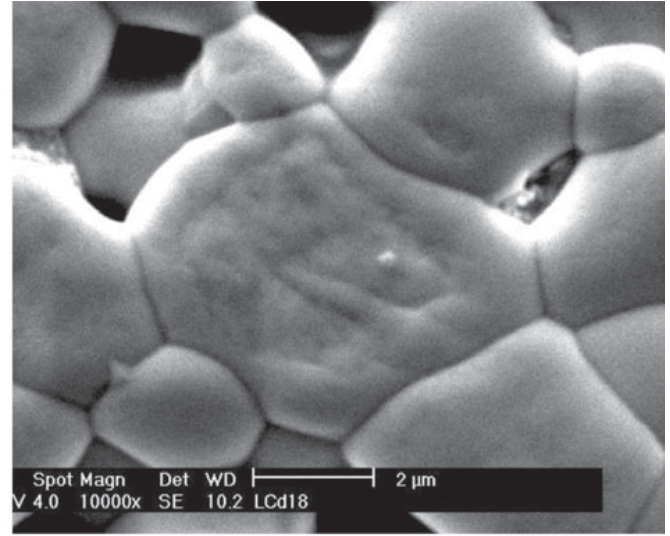

b)

Figure 7. SEM micrographs of the polished and thermally etched surfaces of the samples obtained from $\mathrm{LaCr}_{0.7} \mathrm{Co}_{0.3} \mathrm{O}_{3}$ powders synthesized by conventional mechanical mixing (a); combustion reaction process (b).

connect fuel cells applications. However the combustion reaction method with the optimized variables may result in a simpler, faster and more economic route to produce a homogeneous powder with nanometric dimensions.

Summary: In this paper materials and their synthesis processing investigated at IPEN in a SOFC research program has been reported. The aim of the project is stationary electric power generation. The materials studied were yttriastabilized zirconia (YSZ) as the electrolyte, strontium-doped manganite as the cathode, nickel-YSZ cermet as the anode and cobalt-doped lanthanum chromite as interconnect. These materials have been used in the most SOFC systems known for operating temperatures around $1000{ }^{\circ} \mathrm{C}$. The future direction of this program deals with the ceramic processing technology of a planar SOFC stack, where the electrolyte or the anode ensures the mechanical stability of the cells. Slurry deposition techniques and co-firing processes have been investigated for this purpose.

\section{Acknowledgements}

The authors wish to thank FAPESP/SP/Brazil and CNPq/ Brazil for financial support.

\section{References}

1. Minh, N.Q. J. Am. Ceram. Soc., v. 76, p. 563-588, 1993.

2. Koch Soren, Contact Resistence of Ceramic Interfaces Between Materials Used for Solid Oxide Fuel Cell Applications, $\mathrm{PhD}$ Thesis from Technical University of Denmark at the Department of Chemistry, may, 2002.

3. Kilbride, I.P. J. Power Sources, v. 61, p. 167-171, 1996.

4. Kim, J.-W.; Virkar, A.V.; Fung, K.-Z.; Mehta, K.; Singhal, S.C. J. Electrochem. Soc., v. 146, p. 69-78, 1999.

5. Singhal, S.C. Solid State Ionics, v. 135, p. 305-313, 2000.
6. Badwal, S.P.S.; Foger, K. Materials Forum, v. 21, p. 187224, 1997.

7. Mori; M.; Hiei; Y.; Sammes, N.M.; Tompsett, G.A. Electrochem. Soc. Proc., v. 99, p. 347-351, 2000.

8. Park, H.B.; Hong, Y.S.; Kim, S.J. J. Am. Sci. Letter, v. 16, p. 1782-1785, 1997.

9. Taimatsu, H.; Wada, K.; Kaneko, H.A. J. Am. Ceram. Soc., v. 75, p. 401, 1992.

10. Huang, K.; Feng, M.; Goodenough, J.B.; Schmerling, M. J. Electrochem. Soc., v. 143, p. 3630, 1996.

11. Hammouche, A.; Siebert, E.; Hammou, A. Mater. Res. Bull., v. 24, p. 367, 1989.

12. Kuo, J.H.; Anderson, H.U.; Sparlin, D.M. J. Solid State Chem., v.87, p. 55, 1990.

13. Yamamoto, O.; Takeda, Y.; Kanno, R.; Noda, M. Solid State Ionics, v. 22, p. 241-246, 1987.

14. Gharbage, B.; Henaultet, M.; Pagnier, T.; Hammou, A. Mat. Res.Bull., v. 26, p. 1001, 1991.

15. Segal, D. Key. Eng. Mater, v. 153-154, p. 241-250, 1998.

16. Lazar, D.R.R.; Menezes, C.A.B.; Ussui, V.; Bressiani, A.H.A.; Paschoal, J.O.A. J. Eur.Ceram.Soc., v. 22, p. 2813-2820, 2002.

17. Park, Y.M.; Choi, G.M. Solid State Ionics, v. 120, p. 265274, 1999.

18. Marinsek, M.; Zupan, K.; Macek, J. J. Power Sources, v. 86, p. 383-389, 2000.

19. Groupp, L.; Anderson, H.U. J.Am. Ceram.Soc., v. 59, p. 49-50, 1976.

20. Chick, L.A.; Bates, J.L.; Pederson, L.R.; Kissinger, H.E. Proceeding of the First International Symposium on Solid Oxide Fuel Cells. Ed. By S.C. Singhal. The Electrochemical Society, Pennington, NY, p.170-87, 1989.

21. Segadães, M.; Morelli, M.R.; Kiminami, R.G.A. J. Eur. Ceram. Soc., v. 18, p. 771-781, 1998. 